\title{
SOLUBILIZATION AND CHROMATOGRAPHIC SEPARATION OF GONADOTROPIN RECEPTOR FROM ADENYLATE CYCLASE IN OVARIAN PREPARATIONS*
}

\author{
K.K. Sen and K.M.J. Menon ${ }^{\star \star}$ \\ Endocrine Laboratory \\ Departments of Obstetrics and Gynecology \\ and Biological Chemistry \\ The University of Michigan Medical School \\ Ann Arbor, MI 48109
}

\section{Received December 28,1979}

Summary: The distribution of gonadotropin receptor and adenylate cyclase activities has been monitored in Sepharose 6B chromatographic eluates of a Lubrol solubilized fraction of 25 day old rat ovarian tissue. The receptor was resolved from the adenylate cyclase activity. Chromatography of a gonadotropin desensitized rat ovarian preparation showed that the desensitized preparation contained normal amounts of the adenylate cyclase activity when compared with the control ovarian preparation, but there was a marked reduction in the receptor activity in the desensitized ovaries. This study demonstrates that in ovarian tissue adenylate cyclase is a separate entity distinct from the receptor molecule and that the desensitization causes a reduction in the receptor activity with no detectable change in the catalytic and chromatographic properties of the adenylate cyclase.

\section{INTRODUCTION}

Down regulation of ovarian $L H$ receptors has been reported following a single injection of $\mathrm{hCG}(1,2)$. Kinetic analysis of the binding reaction revealed that the loss of receptor following hormone injection is due to a decrease in the receptor number rather than a change in the affinity of the receptor. Since the loss of receptor activity is accompanied by a loss of hormone induced cyclic AMP accumulation, we have attempted to examine the properties of the receptor and adenylate cyclase following solubilization and chromatography on gel filtration columns. Our results suggest that $i$ ) the hCG receptor and adenylate cyclase exist as physically separable entities in the rat ovary and $i i)$ pretreatment of rats with hCG results in the loss of ovarian hCG receptor with no change in the adenylate cyclase component with

*Supported by NIH Grant HO 06656

**To whom correspondence should be addressed 
respect to its elution properties from Sepharose $6 B$ columns as well as its stimulation by fluoride and magnesium ion.

MATERIALS AND METHODS

Materials

$[\alpha-32 p]$ Adenosine triphosphate was purchased from ICN Chemical and Radioisotope Division, Irvine, California. Cyclic [ $\left.{ }^{3} \mathrm{H}\right]$ adenosine $3^{\prime}, 5^{\prime}-$ monophosphate was purchased from Amersham-Searle. [125I] hCG was prepared by the procedure of Catt et al. (3). Unlabeled hCG used in these studies was generously donated by $\overline{\mathrm{Dr}}$. Robert E. Canfield, Columbia University and the Center for Population Research, NICHD. All other chemicals used were conventiona? commercial products.

Assay of adenylate cyclase: The procedure of Salomon et al. (4) was used for the assay of adenylate cyclase. This involved incubation of samples with $\left[\alpha-{ }^{32} P\right]$ ATP followed by chromatographic separation of [32P] CAMP from other metabolites of ATP on Dowex and Al umina colums. The recovery of CAMP on the columns was monitored by the addition of [ $\left.{ }^{3} \mathrm{H}\right]$ cAMP after the incubation step and by determining the amount of $\left[{ }^{3} \mathrm{H}\right]$ cAMP recovered in the column effluents.

Assay of hCG receptor activity: The receptor activity was assayed in the soluble fraction and the column effluents by the procedure described previously from our laboratory (5). Seventy microliters of the col umn effluent were incubated with $80,000 \mathrm{cpm}$ [125 I] hCG in the presence of $230 \mu 1$ buffer containing $25 \mathrm{mM}$ Tris $\mathrm{HCl}, \mathrm{pH} 7.5,1 \mathrm{mM} \mathrm{CaCl}$, and $0.1 \% \mathrm{BSA}$ in a final volume of 300 ul. After incubation at $37 \mathrm{C}$ for $30 \mathrm{~min}, 200 \mu 1$ of 0.1 M sodium phosphate buffer, $\mathrm{pH} 7.5,0.5 \mathrm{ml}$ of $0.2 \% \gamma$-globulin in $0.1 \mathrm{M}$ sodium phosphate, $\mathrm{pH} 7.5$, and $0.1 \mathrm{ml}$ of $25 \%$ polyethylene glycol were added, and the contents were mixed well. The resultant precipitate was centrifuged at $6,000 \mathrm{rpm}$ for 10 min in a Sorvall centrifuge fitted with an $5 \$ 34$ rotor. The supernatant was decanted and the sediment was resuspended in $0.5 \mathrm{ml}$ of $25 \mathrm{mM}$ Tris $\mathrm{HCl}$,

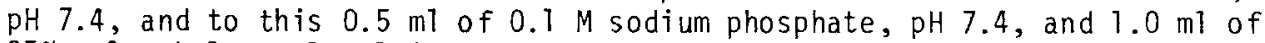
$25 \%$ polyethylene glycol in phosphate buffer were added. The mixture was vortexed well and the precipitate was centrifuged as in the first step. The supernatant was discarded, and the residue was suspended in $0.5 \mathrm{mi}$ phosphate buffer and radioactivity determined in a gamma counter. A parallel incubation was carried out under similar conditions with the exception that 1000fold excess unlabeled hCG was also included in the assay. The specific binding was determined by subtracting from the total radioactivity the amount of radioactivity associated with incubations containing 1000-fold excess hCG.

Solubilization of hCG-receptor and adenylate cyclase activities: Although conditions for the solubilization of either hCG-receptor alone (5) or adenylate cyclase $(6,7)$ have been described in the ovarian tissue, the present experimental design necessitated simultaneous assay of hCG receptor and adenylate cyclase activities in column effluents. Thus, ideal conditions were sought in which both activities could be solubilized and recovered with satisfactory yield. Although $1 \%$ Triton $X-100$ caused $74 \%$ solubilization of the receptor activity with $30 \%$ recovery of the receptor at the end of the centrifugation step, this procedure caused marked inhibition of the adenylate cyclase activity. Sonication also caused complete destruction of adenylate cyclase activity. Approximately $50 \%$ of both activities were solubilized when the ovarian tissue was homogenized in a medium containing $50 \mathrm{mM}$ Tris $\mathrm{HCl}, \mathrm{PH} 7.4$, $7 \mathrm{mM}$ EDTA, $5 \mathrm{mM} \mathrm{MgCl} 2,5 \mathrm{mM} \mathrm{KF}, 0.25 \mathrm{M}$ sucrose and $2 \%$ Lubrol $\mathrm{PX}$. The solubilization procedure was carried out as follows: Fresh ovarian tissue or frozen bovine corpus luteum was weighed, cut into small pieces and homoge- 
nized for 1 minute in 2 vols of the homogenizing buffer of the composition described above in a glass homogenizer with a loose fitting teflon pestle. During homogenization, care was taken to avoid heating by immersing the homogenizer in an ice slush throughout the procedure. After procedure, the homogenate was kept in ice for $1 \mathrm{~h}$. This was followed by centrifugation at $6500 \times \mathrm{g}$ for $15 \mathrm{~min}$ and the resulting supernatant was further centrifuged at $150,000 \times g$ for $1 \mathrm{~h}$. The resulting supernatant is the soluble fraction.

Sepharose column chromatography: Under our experimental conditions, [1 $\angle 5 \mathrm{I}]$ hCG binding activity was found to be very labile on storage after solubilization and chromatography. For this reason, we used small col umns $(24 \times 0.9 \mathrm{~cm}$ internal diameter) and both the activities were assayed in the col umn effluents on the same day as chromatography. The soluble fraction $(0.7 \mathrm{ml})$ was applied to the column which has been previously equilibrated with the homogenizing buffer containing $0.2 \%$ Lubrol. The column was eluted with a medium containing $50 \mathrm{mM}$ Tris $\mathrm{HCl}$, pH 7.4, I $\mathrm{mM}$ EDTA, $5 \mathrm{mM} \mathrm{MgCl} 2,5 \mathrm{mM} \mathrm{KF}$, $0.25 \mathrm{M}$ sucrose and $0.2 \%$ Lubrol $\mathrm{PX}$ at a flow rate of $4 \mathrm{ml} / \mathrm{h}$. One $\mathrm{ml}$ fractions were collected.

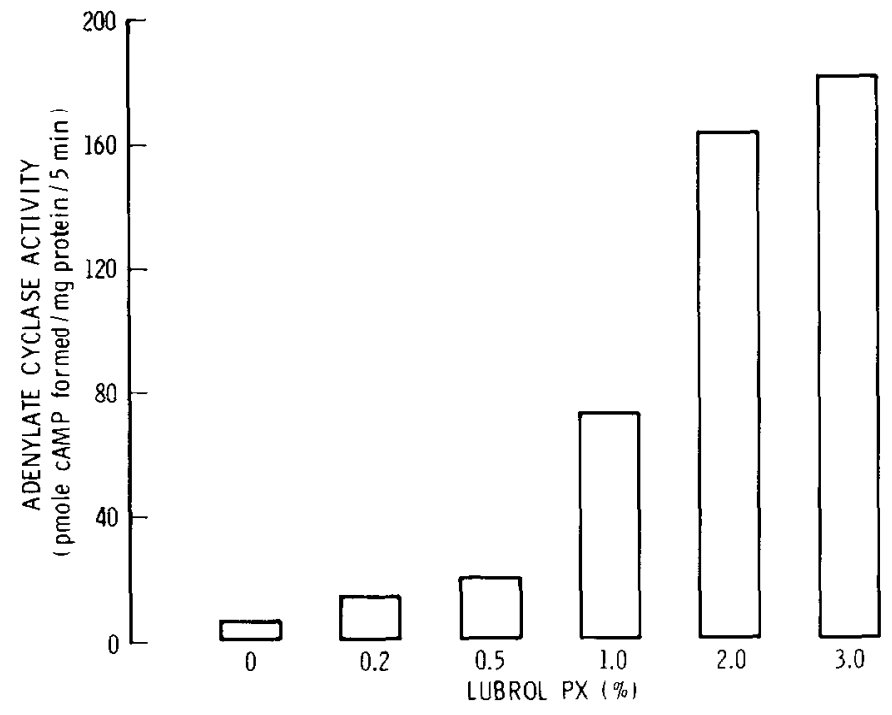

Fig. I Effect of increasing Lubrol concentrations on solubilization of adenylate cyclase from rat ovary.

Ovaries collected from 26 day old rats were pooled. Each pool contained the tissues from 10 rats. The pooled tissue was homogenized for 1 min in 2 volumes of buffer containing $50 \mathrm{mM}$ Tris $\mathrm{HCl}$, $\mathrm{pH} 7.4,1 \mathrm{mM}$ EDTA, $5 \mathrm{mM} \mathrm{MgCl} 2,5 \mathrm{mM} \mathrm{KF}, 0.25 \mathrm{M}$ sucrose and $0,0.2$, $0.5,1.0,2.0$ or $3.0 \%$ Lubrol $\mathrm{PX}$. Further details concerning the homogenization procedure are described in the text. The homogenate was allowed to remain at $4 \mathrm{C}$ for $\mathrm{l} \mathrm{hr}$ and then centrifuged at $6500 \times \mathrm{g}$ for $15 \mathrm{~min}$. The supernatant was further centrifuged at $150,000 \times \mathrm{g}$ for $1 \mathrm{hr}$. The resulting supernatant is the soluble enzyme. Twenty-five microliters of this preparation was then tested for adenylate cyclase activity. The results are the means of three deterninations. 


\section{RESULTS}

The effect of increasing concentrations of Lubrol PX on solubilization of adenylate cyclase: The yield of adenylate cyclase in the $105,000 \times \mathrm{g}$ supernatant fraction increased with increasing concentrations of Lubrol PX up to $2 \%$ (Fig. 1). Thus, $2 \%$ Lubrol PX was chosen for subsequent solubilization

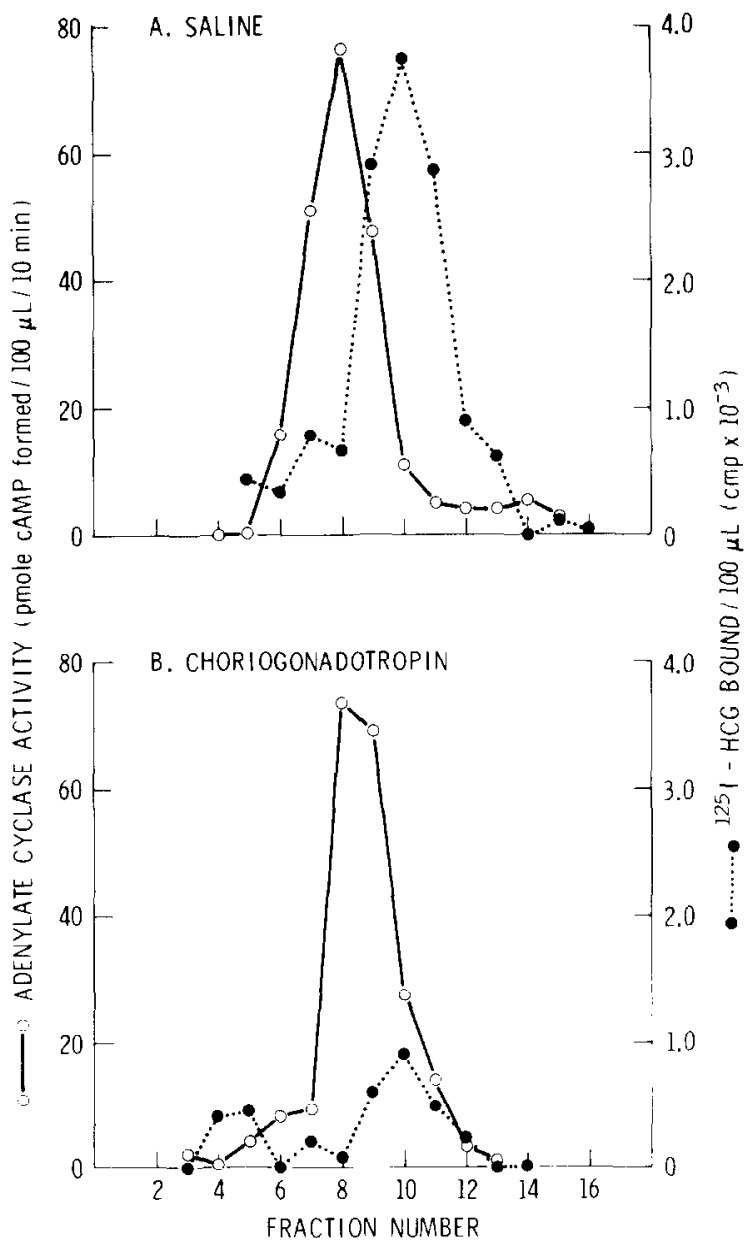

Fig. 2 Effect of hCG injection on [125I] hCG binding and adenylate cyclase activities. Panel A, control; Panel B, hCG injected group.

Ten rats (26 day old) were injected with $25 \mathrm{IU}$ of hCG in $0.2 \mathrm{ml}$ subcutaneously. A control group of 10 rats was injected with an equal volume of saline. Twenty-four hrs later both groups were sacrificed, ovaries removed and the tissue from the respective groups pooled and weighed. The ovaries were then solubilized and the soluble fractions applied to Sepharose $6 \mathrm{~B}$ column $(24 \mathrm{~cm} \times 0.9 \mathrm{~cm}$ I.D.) which had been equilibrated with the same buffer containing $0.2 \%$ Lubrol PX. The column was run at a flow rate of $4 \mathrm{ml} / \mathrm{hr}$ and $1.0 \mathrm{ml}$ fractions were collected. An aliquot $(70 \mu 1)$ of each fraction was assayed for [125I] hCG binding (-.-) and adenylate cyclase activity ( $)$. 
experiments. Although the receptor activity was also solubilized with Triton $x-100$, this treatment completely destroyed adenylate cyclase activity. Thus, Lubrol PX was the detergent of choice for solubilization of both the activities.

Effect of in vive treatment with hCG on [125] hCG binding and adenylate cyclase activities in the column effluents: 25 day old rats were treated with 25 IU hCG subcutaneously, and 24 hrs later they were sacrificed by cervical dislocation and the ovaries removed. A control group was treated with an equal volume of saline. The ovaries of both groups were separately homogenized in two volumes of the homogenizing buffer, and the soluble fraction was prepared as described under "Materials and Methods."

Figure 2 depicts the chromatographic profile of the hormone treated (Panel B) and control (Panel A) ovaries when assayed for [125I] hCG binding and adenylate cyclase activities. As can be seen, both activities were resolved from one another on the column under the experimental conditions. In addition, as expected, there was a marked decrease in [125 I] hCG receptor activity in the experiments employing ovaries prepared from animals treated with hCG compared to the group of animals not treated with hCG. By contrast, pretreatment with hCG produced no change either in the position of elution of adenylate cyclase or in the total yield of enzyme activity.

Fluoride and $\mathrm{Mg}^{2+}$ dependency of adenylate cyclase: The adenylate cyclase in the column effluents was then tested with respect to its stimulation by fluoride and $\mathrm{Mg}^{2+}$ ions.

The effect of increasing fluoride concentration on adenylate cyclase is shown in Fig. 3. In ovaries from both hormone injected and control groups, the concentration of fluoride ion required for maximal activity was $30 \mathrm{mM}$. In both instances, the enzyme activity declined with a further increase in fluoride concentration. The fluoride dependency for adenylate cyclase in both the control and hormone injected groups were identical. 


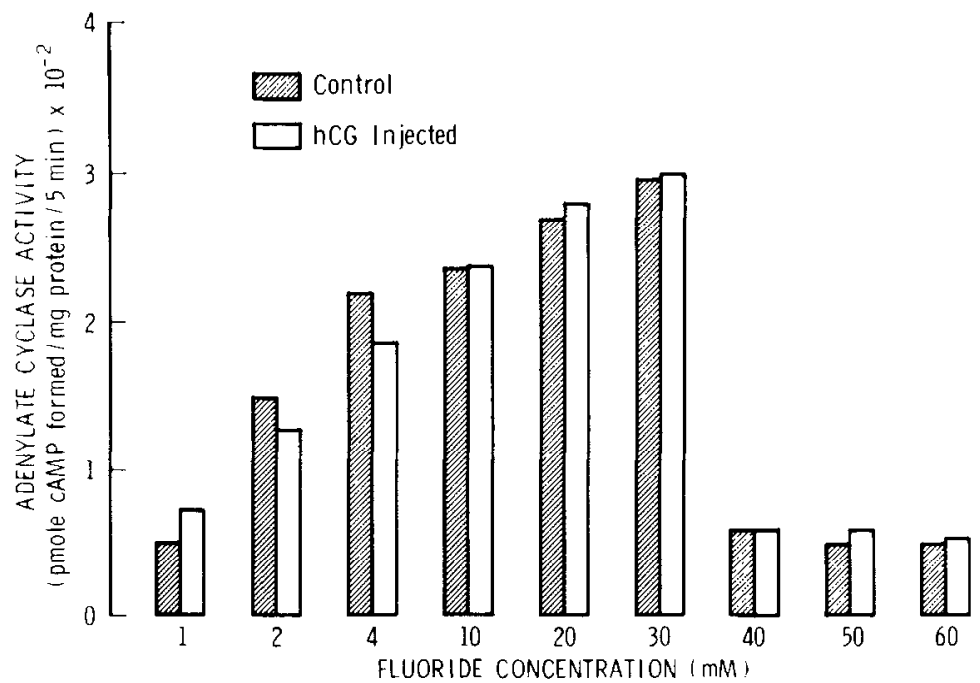

Fig. 3 Effect of increasing concentrations of fluoride ion on adenylate cyclase activity in Sepharose $6 B$ column effluents of soluble rat ovarian preparations.

Sepharose $6 \mathrm{~B}$ fractions containing the peak of adenylate cyclase activity were pooled and assayed in the presence of varying concentrations of fluoride.

The effect of increasing concentrations of $\mathrm{Mg}^{2+}$ on adenylate cyclase activity was the same in the control and hormone injected groups (Fig. 4). In both cases, the concentration of $\mathrm{Mg}^{2+}$ for optimal activity was $5 \mathrm{mM}$, and at higher concentrations it caused a slight inhibition.

\section{DISCUSSION}

Although there is considerable reference to the fact that the binding of gonadotropins to the ovarian receptors and subsequent activation of adenylate cyclase are early events in hormone action in the ovary, knowledge of the physical association between receptor and adenylate cyclase in ovarian tissue is relatively slight. In the $\beta$-adrenergic system, adenylate cyclase has been shown to be separable from $\beta$-adrenergic receptor $(8,9,10,11)$. Thus our attention was focused primarily on the simultaneous solubilization of both activities and their possible physical separation on gel filtration columns. The best success was achieved when small columns were employed which cut down the dilution of the two activities as well as the duration of exposure of the activities on the columns. Under the present experimental conditions, 


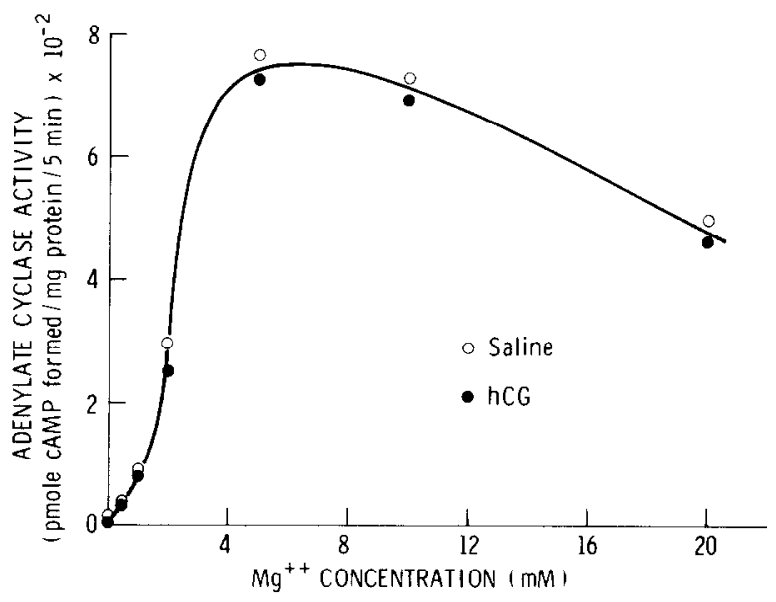

Fig. 4 Effect of increasing concentrations of $\mathrm{Mg}^{2+}$ ion on adenylate cyclase activity in Sepharose 6B col umn effluents of ovarian preparations from control and hCG injected animals.

The experimental conditions are similar to that described for Fig. 3 with the exception that adenylate cyclase assay was carried out with different concentrations of $\mathrm{Mg}^{2+}$ ion. Each assay was carried out in triplicate.

the adenylate cyclase activity can be stored up to 1 week at $-20^{\circ} \mathrm{C}$, whereas the receptor suffered rapid loss of activity upon storage.

The chromatographic profile of the solubilized ovarian extract on Sepharose $6 \mathrm{~B}$ columns revealed that the receptor was separable from the fluoride stimulated adenylate cyclase. However, two important factors seemed to influence the separation of the receptor from the cyclase on Sepharose columns. First, it was absolutely necessary to include Lubrol in the elution buffer. In the absence of Lubrol, the proteins seemed to aggregate, affecting the separation. Second, it was also critical to make certain that the soluble fraction was free of the light microsomal particles. Dufau et al. (12) also have reported that the adenylate cyclase is separable from the receptor in the luteinized rat ovary.

We have also demonstrated that the decrease in the hCG receptor concentration observed after in vivo injection of hCG does not affect the concentration or the properties of the adenylate cyclase as evidenced by a decrease in [125I] hCG binding component in the hCG injected group with normal adenylate cyclase activity (Fig. 2). In addition, in the desensitized state, ovarian 
adenylate cyclase was fully active in agreement with previous observations that, in the desensitized state, cholera toxin did stimulate the adenylate cyclase activity $(2,13)$.

\section{REFERENCES}

1. Conti, M., Harwood, J.P., Hsueh, A.J.W., Dufau, M.L., and Catt, K.J. (1976) J. Biol. Chem. 251:7729-7731.

2. Sen, K.K., Azhar, S., and Menon, K.M.J. (1979) J. Biol. Chem. 254: 5664-5671.

3. Catt, K.J., and Dufau, M. (1973) Adv. Exp. Med. and Bio1. 36:379-418.

4. Salomon, Y., Londos, C., and Rodbe11, M. (1974) Ana1. Biochem. 58:541-548

5. Thambyrajah, V., Azhar, S., and Menon, K.M.J. (1976) Biochim. Biophys. Acta 428:35-44.

6. Young, J.L., and Stansfield, D. (1978) Biochem. J. 169:133-142.

7. Young, J.L., and Stansfield, D.A. (1978) Biochem. J. 173:919-924.

8. Limbird, L.E., and Lefkowitz, R.J. (1977) J. Biol. Chem. 252:799-802.

9. Orly, J., and Schramm, M. (1976) Proc. Nat1. Acad. Sci. 73:4410-4414.

10. Insel, P.A., Maguire, M.E., Gilman, A.G., Bourne, H.R., Coffino, P., and Me1mon, K.L. (1976) Mol. Pharmaco1. 12:1062-1069.

11. Charness, M.E., Byl und, D.B., Beckman, B.S., Hollenberg, M.D., and Snyder, S.H. (1976) Life Sci. 19:243-249.

12. Dufau, M.L., Hayashi, K., Sala, G., Baukal, A., and Catt, K.J. (1978) Proc. Nat1. Acad. Sci. U.S.A. 75:4769-4773.

13. Conti, M., Harwood, J.P., Dufau, M.J., and Catt, K.J. (1977) Molec. Pharmacol. 13:1024-1032. 